\title{
Recessive Resistance to Bean common mosaic virus Conferred by the bc-1 and $b c-2$ Genes in Common Bean (Phaseolus vulgaris) Affects Long-Distance Movement of the Virus
}

\author{
Xue Feng, Gardenia E. Orellana, James R. Myers, and Alexander V. Karasev ${ }^{\dagger}$
}

First, second, and fourth authors: Department of EPPN, University of Idaho, Moscow; third author: Department of Horticulture, Oregon State University, Corvallis; and fourth author: Bioinformatics and Computational Biology Program, University of Idaho, Moscow. Accepted for publication 6 April 2018.

\begin{abstract}
Recessive resistance to Bean common mosaic virus (BCMV) in common bean (Phaseolus vulgaris) is governed by four genes that include one strainnonspecific helper gene $b c-u$, and three strain-specific genes $b c-1, b c-2$, and $b c-3$. The $b c-3$ gene was identified as an eIF4E translation initiation factor gene mediating resistance through disruption of the interaction between this protein and the VPg protein of the virus. The mode of action of $b c-1$ and $b c-2$ in expression of BCMV resistance is unknown, although $b c-1$ gene was found to affect systemic spread of a related potyvirus, Bean common mosaic necrosis virus. To investigate the possible role of both $b c-1$ and $b c-2$ genes in replication, cell-to-cell, and long-distance movement of BCMV in $P$. vulgaris, we tested virus spread of eight BCMV isolates representing pathogroups I, IV, VI, VII, and VIII in a set of bean differentials expressing different combinations of six resistance alleles including $b c-u, b c-1, b c-1^{2}$, $b c-2, b c-2^{2}$, and $b c-3$. All studied BCMV isolates were able to replicate and

spread in inoculated leaves of bean cultivars harboring $b c-u, b c-1, b c-1^{2}$, $b c-2$, and $b c-2^{2}$ alleles and their combinations, while no BCMV replication was found in inoculated leaves of cultivar IVT7214 carrying the $b c-u, b c-2$, and $b c-3$ genes, except for isolate $1755 \mathrm{a}$, which was capable of overcoming the resistance conferred by $b c-2$ and $b c-3$. In contrast, the systemic spread of all BCMV isolates from pathogroups I, IV, VI, VII, and VIII was impaired in common bean cultivars carrying $b c-1, b c-1^{2}, b c-2$, and $b c-2^{2}$ alleles. The data suggest that $b c-1$ and $b c-2$ recessive resistance genes have no effect on the replication and cell-to-cell movement of BCMV, but affect systemic spread of BCMV in common bean. The BCMV resistance conferred by $b c-1$ and $b c-2$ and affecting systemic spread was found only partially effective when these two genes were expressed singly. The efficiency of the restriction of the systemic spread of the virus was greatly enhanced when the alleles of $b c-1$ and $b c-2$ genes were combined together.
\end{abstract}

Bean common mosaic virus (BCMV) is a member of the genus Potyvirus, having a single-stranded, positive-sense RNA genome of approximately $10-\mathrm{kb}$, excluding poly(A) at the $3^{\prime}$-terminus, with a virus-encoded $\mathrm{VPg}$ protein covalently attached to the $5^{\prime}$-terminus (Adams et al. 2012). The virus genome encodes a single polyprotein that is co- and posttranslationally cleaved by three virus-specific proteases into 10 mature proteins (Adams et al. 2012), and an out-of-frame, small nonstructural protein PIPO (Chung et al. 2008; Wei et al. 2010). BCMV exists as a complex of strains defined genetically by interactions with resistance genes available in a panel of differential bean cultivars (Drijfhout 1978, 1991; Drijfhout and Morales 2005; Feng et al. 2015). These various genetic strains displayed a high level of sequence diversity, with up to $16 \%$ nucleotide sequence difference among them for the whole genome, and with multiple recombinants identified (Feng et al. 2014a, b, 2015; Flasinski et al. 1996; Larsen et al. 2005; Li et al. 2016; Naderpour et al. 2009; Zhou et al. 2014). Two major parents were identified among the BCMV recombinants, strain US1 (GenBank accession number KT175569) and strain RU1 (KF919300); however, multiple other, minor parental sequences were found present in the recombinants representing other BCMV strains (Feng et al. 2015).

${ }^{\dagger}$ Corresponding author: A. V. Karasev; E-mail: akarasev@uidaho.edu

Funding: This work was funded in part through grants from the Idaho Bean Commission, Idaho State Department of Agriculture, U.S. Department of AgricultureNational Institute of Food and Agriculture Hatch project IDA01560, and by the Idaho Agricultural Experiment Station.

*The $\boldsymbol{e}$-Xtra logo stands for "electronic extra" and indicates that two supplementary tables are published online.

(c) 2018 The American Phytopathological Society
BCMV is a seed-transmissible pathogen representing a significant threat to common bean (Phaseolus vulgaris L.) worldwide; in the field, BCMV can be transmitted by multiple species of aphids (Bos 1971; Drijfhout and Morales 2005; Flores-Estevez et al. 2003; Morales and Bos 1988). Resistance to BCMV in common bean is governed by one dominant $I$ gene, and four recessive genes, $b c-u$, $b c-1, b c-2$, and $b c-3$; three of the recessive genes, $b c-1, b c-2$, and $b c-3$ have two alleles each, which results in eight resistance alleles expressed against BCMV (Drijfhout 1978; Hart and Griffiths 2013; Kelly et al. 1995). The dominant $I$ gene confers extreme resistance or immunity against all strains of BCMV when the temperature stays below $30^{\circ} \mathrm{C}$, and variable types of local and systemic necrosis when temperature exceeds $30^{\circ} \mathrm{C}$ (Ali 1950; Collmer et al. 2000; Fisher and Kyle 1994). The mode of action of the $I$ gene was identified as hypersensitive resistance or induced cell death (CadleDavidson and Jahn 2005; Collmer et al. 2000). Of the six recessive resistance alleles, $b c-u$ was found to be a helper allele, not conferring resistance by itself but necessary for the expression of BCMV resistance by the other five alleles, $b c-1, b c-1^{2}, b c-2, b c-2^{2}$, and $b c-3$ (Drijfhout 1978; Kelly et al. 1995). Another of the recessive alleles, $b c-3$, is capable of protecting common bean against almost all strains of BCMV when present together with the $b c-u$ helper (Drijfhout 1978; Feng et al. 2015; Kelly et al. 1995; Naderpour and Johansen 2011), and was later identified as the $e I F 4 E$ allele carrying a mutated eukaryotic translation initiation factor gene (Hart and Griffiths 2013; Naderpour et al.2010). The mechanism of the resistance conferred by $b c-3$ to BCMV and other potyviruses is related to the block of replication of $\mathrm{BCMV}$ due to the impaired interaction between eIF4E protein and the VPg protein covalently linked to the $5^{\prime}$ terminus of a potyvirus genome (Hart and Griffiths 2013; Naderpour et al. 2010).

The other four alleles, $b c-1, b c-1^{2}, b c-2$, and $b c-2^{2}$, confer resistance to BCMV that is highly strain-specific (Drijfhout 1978; 
Kelly et al. 1995). These four resistance alleles, $b c-1, b c-1^{2}, b c-2$, and $b c-2^{2}$, are primarily responsible for the large number of pathogroups (PGs), numbered from I to VIII, defined in the BCMV complex based on resistance or susceptibility in a panel of 11 to 12 differential common bean cultivars carrying resistance genes in various combinations (Drijfhout 1978; Drijfhout and Morales 2005; Feng et al. 2015). Based on susceptibility to different pathogroups/ strains of BCMV, common bean cultivars were grouped into host groups (HGs) numbered 0 to 11 carrying different combinations of the BCMV resistance alleles (Drijfhout and Morales 2005). Recently, $b c-1$ and $b c-1^{2}$ alleles were found associated with the impaired systemic movement of the NL8 strain of a related potyvirus, Bean common mosaic necrosis virus (BCMNV), in common bean (Feng et al. 2017). However, the mode of action of either $b c-1$ or $b c-2$ recessive resistance genes against $\mathrm{BCMV}$ is unknown, which prompted our interest in mechanisms of $b c-1$ - and $b c-2$ mediated resistance to BCMV in common bean.

During biological and molecular characterization of several field-collected isolates of BCMV, we encountered a lack of symptom expression in noninoculated leaves of bean cultivars from HG-2, $-3,-4$, and -6 when infected with some BCMV isolates. These same BCMV isolates were found to invade systemically only a proportion of the asymptomatic upper, noninoculated leaves in common bean cultivars from $\mathrm{HG}-2,-3,-4$, and -6 , suggesting only partial effectiveness of the $b c-1$ and $b c-2$ resistance alleles. To address possible modes of action of the recessive resistance genes $b c-1$ and $b c-2$ in $P$. vulgaris, we subjected a set of eight isolates of BCMV from PGs I, IV, VI, VII, and VIII to a systematic study in a set of bean differentials expressing different combinations of six resistance alleles including $b c-u, b c-1, b c-1^{2}, b c-2, b c-2^{2}$, and $b c-3$. Two types of virus functions were assessed: replication and cellto-cell movement in the inoculated leaves, and subsequent longdistance movement of the virus to the upper, noninoculated leaves. Expression of $b c-1$ and $b c-2$ alleles in common bean cultivars was associated with the lack of or impaired long-distance movement of BCMV.

\section{MATERIALS AND METHODS}

Virus sources and maintenance. The origins of BCMV isolates RU1-P, RU1-OR, and 1755a were described previously (Feng et al. 2014a, b, 2015). BCMV isolate 3915 was found in field sample 91-3915 collected in Willamette Valley, OR in 2012. BCMV isolates 3PF, RU1-CA, and PG1 were collected in 2015 near Davis, CA, by P. Guzman as field samples from heirloom cultivars of common bean. Isolate 313615 was found in 2013, in a sample of common bean exhibiting mosaic received from a common bean germplasm collection of the USDA-ARS Plant Germplasm Unit, Pullman, WA, provided by J. Thayer. BCMV isolate Viva2 was collected from a common bean plant exhibiting mosaic, at the VIVA farm near La Conner, WA in 2016. All virus isolates were propagated in the bean cultivar Dubbele Witte using mechanical inoculation and maintained under greenhouse conditions as described previously (Feng et al. 2014a).

Biological and serological characterization. The biological characterization of BCMV isolates 3915, 3PF, Viva2, PG1, 313615, and RU1-CA on a set of 11 bean differentials (Drijfhout 1978) was performed as described previously for BCMV typing (Table 1) (Feng et al. 2014a, b). Later, an expanded set of experiments on a subgroup of seven bean cultivars lacking the $I$ gene and carrying different recessive resistance gene combinations was added to assess the replication, cell-to-cell, and long-distance movement of field isolates under study, in comparison with our control BCMV isolates RU1-P, RU1-OR, and 1755a in these same seven cultivars (Table 2 ). In the latter experiment, all seven common bean lines were inoculated with each isolate (two or three plants per cultivar), and plants were placed in a climate-controlled growth room with standard summer-time growth conditions (16-h day photoperiod and daytime/nighttime temperatures of $25 / 16^{\circ} \mathrm{C}$ ). Symptoms were recorded at weekly intervals, for 5 weeks postinoculation (wpi). For each cultivar, inoculated leaves were collected and tested at 2 wpi; every upper, noninoculated leaf was collected for a triple-antibody sandwich-enzyme linked immunosorbent assay (TAS-ELISA) test at 5 wpi. To test the virus presence in leaf tissue, 0.3- to 0.5-g pieces were cut from each leaf, ground in meshed extraction bags (Bioreba AG, Reinach, Switzerland) using the ELISA extraction buffer (1:10 ratio, wt/vol), and 100- $\mu$ l aliquots of the leaf extracts were loaded onto precoated ELISA plates as described (Feng et al. 2014b). TAS-ELISA tests using BCMVspecific, polyclonal antibodies produced in two different species, rabbit (coating antibody) and guinea pig (detecting antibody), from the laboratory collection were performed as described previously (Feng et al. 2014b).

Cloning strategy, sequencing, and sequence analysis. The whole-genome cloning for BCMV isolates 3915, 3PF, 313615, PG1, and Viva2 included initial amplification of overlapping RT-PCR fragments as described previously (Feng et al. 2014b). Eight pairs of primers were used, designed based on the aligned BCMV sequences available in the GenBank database (Supplementary Table S1). RU1-CA genome was amplified by RT-PCR using RU1-P specific

TABLE 1. Disease and enzyme linked immunosorbent assay (ELISA) reactions of common bean (Phaseolus vulgaris) differentials inoculated with Bean common mosaic virus (BCMV) isolates ${ }^{\text {a }}$

\begin{tabular}{|c|c|c|c|c|c|c|c|c|}
\hline \multirow[b]{2}{*}{ Bean cultivar ${ }^{\mathrm{b}}$} & \multirow[b]{2}{*}{ Resistance genes } & \multirow[b]{2}{*}{$\mathrm{HG}^{\mathrm{c}}$} & \multicolumn{6}{|c|}{ BCMV isolates tested } \\
\hline & & & 3PF (PG-I) & Viva2 (PG-I) & 313615 (PG-I) & PG1 (PG-I) & 3915 (PG-IV) & RU1-CA (PG-VI) \\
\hline DW & None & 0 & $+/+$ & $+/+$ & $+/+$ & $+/+$ & $+/+$ & $+/+$ \\
\hline SGR & $i, b c-u$ & 1 & $+/+$ & $+/+$ & $+/+$ & $+/+$ & $+/+$ & $+/+$ \\
\hline RGLC & $i, b c-u, b c-1$ & 2 & $-1-$ & $-1-$ & $-1-$ & $-1-$ & $+/+$ & $+/+$ \\
\hline RGLB & $i, b c-u, b c-1^{2}$ & 3 & $-1-$ & $-1-$ & $-1-$ & $-1-$ & $+/+$ & $+/+$ \\
\hline Sanilac & $i, b c-u, b c-2$ & 4 & $-1-$ & $-1-$ & $-1-$ & $-1-$ & $-1-$ & $+/+$ \\
\hline UI 35 & $i, b c-u, b c-1^{2}, b c-2^{2}$ & 6 & $-1-$ & $-1-$ & $-1-$ & $-1-$ & $-1-$ & $-1-$ \\
\hline IVT7214 & $i, b c-u, b c-2, b c-3$ & 7 & $-1-$ & $-1-$ & $-1-$ & $-1-$ & $-1-$ & $-1-$ \\
\hline Jubila & $I, b c-1$ & 9 & $-1-$ & $-1-$ & $-1-$ & $-1-$ & $-1-$ & $-1-$ \\
\hline Amanda & $I, b c-1^{2}$ & 10 & $-1-$ & $-1-$ & $-1-$ & $-1-$ & $-1-$ & $-1-$ \\
\hline US1006 & $I, b c-u, b c-2^{2}$ & 11 & $-1-$ & $-1-$ & $-1-$ & $-1-$ & $-1-$ & $-1-$ \\
\hline IVT7233 & $I, b c-u, b c-1^{2}, b c-2^{2}$ & 12 & $-1-$ & $-1-$ & $-1-$ & $-1-$ & $-1-$ & $-1-$ \\
\hline
\end{tabular}

${ }^{\text {a }}$ Disease reaction is shown first as a numerator followed by ELISA reaction as a denominator. Three plants were inoculated for each BCMV isolate per experiment and two to three leaf samples were collected randomly from upper uninoculated leaves at 4 to 5 weeks postinoculation. Numerator: $+=$ symptoms on inoculated plants; $-=$ no symptoms on inoculated plants; denominator: + designates ELISA signal $\left(\mathrm{A}_{405}\right)$ in an infected plant exceeding healthy control by 10 -fold; and designates ELISA signal in an infected plant equivalent to that of a healthy control.

b Abbreviations of common bean cultivars: DW, Dubbele Witte; SGR, Stringless Green Refugee; RGLC, Redlands Greenleaf C; and RGLB, Redlands Greenleaf B.

${ }^{c}$ Host resistance group. 
primers (Feng et al. 2014b). The overlapping PCR products were cloned into the AT-vector T-Easy (Promega, Madison, WI) and submitted for sequencing to GENEWIZ (South Plainfield, NJ) as described (Feng et al. 2014b). The 5'-terminal sequences for all six isolates were amplified using the RACE Kit (Roche, Indianapolis, IN), and subsequently cloned and sequenced the same way as the rest of the genome. The complete viral genomes assembled using SeqMan (DNASTAR, Madison, WI) had been deposited in the GenBank database under the accession numbers MH024842 (BCMV-3915), MH024841 (BCMV-3PF), MH024840 (BCMV313615), MH024838 (BCMV-PG1), MH024839 (BCMV-Viva2), and MH024843 (BCMV-RU1-CA). All sequences were initially analyzed using the BLASTn 2.2.17 (Altschul et al. 1997) tool available at the National Center for Biotechnology Information (NCBI). Open reading frames (ORFs) were identified using the ORF Finder program available at the NCBI. Complete sequences of BCMV isolates were aligned using ClustalX Ver. 2.0 (Conway Institute, UCD, Dublin). Further analysis was conducted with the Recombination Detection Program v.4.16 (RDP4) (Martin et al. 2005).

\section{RESULTS}

Variable levels of resistance to different BCMV isolates conferred by recessive resistant genes in common bean cultivars. When screened on the eleven bean differentials, all tested BCMV isolates induced typical mosaic, mottle, raised dark green blistering, leaf deformation, and often growth retardation in susceptible bean cultivars. Based on the pathogenicity profiles exhibited on bean differentials, isolate 3915 was classified as belonging to PG-IV, RU1-CA was classified as belonging to PG-VI, while four remaining isolates were typed as belonging to PG-I (Table 1). However, in the course of biological typing of some of these novel, field BCMV isolates inconsistencies were noted, in particular, occasional presence of the BCMV isolates in upper, noninoculated leaves detected by ELISA in randomly picked leaves that exhibited no symptoms.

For instance, isolate $3 \mathrm{PF}$ was occasionally found present in randomly collected samples from noninoculated leaves of cultivars Redlands Greenleaf C, Redlands Greenleaf B, and Sanilac, detected by ELISA, while the whole plants remained asymptomatic even at 8 wpi. The pathogenicity test on differential lines was repeated multiple times. Isolate $3 \mathrm{PF}$ replicating in upper, asymptomatic leaves of cultivars Redlands Greenleaf C, Redlands Greenleaf $\mathrm{B}$, and Sanilac was also used as inoculum for re-inoculations of bean differentials and found to exhibit the same profile: Dubbele
Witte and Stringless Green Refugee were always found infected systemically and showed typical symptoms induced by BCMV-3PF infection, while Redlands Greenleaf C, Redlands Greenleaf B, and Sanilac never exhibited any sign of infection based on visual symptom observations, however, virus could be detected in some randomly collected, but not all upper noninoculated leaves by ELISA test (Table 2). This suggested the resistance genes incorporated in these cultivars were "leaky" and these cultivars were only partially resistant to BCMV-3PF: virus was able to move systemically to a substantial proportion of upper noninoculated leaves while the rest of noninoculated leaves remained uninfected. Additional experiments including seven bean differentials were performed to study variable levels of resistance conferred by recessive genes to novel and control BCMV isolates and assess replication, cell-to-cell, and systemic movement of BCMV isolates in these cultivars. In these additional experiments, 154 plants were inoculated and tested, the number of leaf samples harvested from each plant varied from 23 to 138 and was cultivar- and inoculum-dependent (Supplementary Table S2). In total, 308 inoculated leaves were tested at 2 wpi, and 6,492 noninoculated leaves were tested at 5 wpi by TAS-ELISA. RU1-P and RU1-CA were both classified as belonging to PG-VI, and whole genomes of these two isolates were found to share 99\% identities to each other (described below). Due to the shortage of space and labor, only RU1-P was subjected to this comprehensive analysis.

When screened on the seven bean differentials lacking the I gene, the biological responses induced by five new and three control BCMV isolates in common bean cultivars carrying different combinations of recessive resistance genes were recorded as symptomatic (typical mosaic and leaf deformations) or asymptomatic (Table 2). Based on the visual symptoms alone observed on differentials, isolates 3PF, 313615, Viva2, and PG1 were found able to systemically infect cultivars Dubbele Witte (HG-0) and Stringless Green Refugee (HG-1), while isolate 3915 infected cultivars Dubbele Witte (HG-0), Stringless Green Refugee (HG-1), Redlands GreenleafC (HG-2), and Redlands Greenleaf B (HG-3) systemically. Control isolates RU1-P, RU1-OR, and 1755a showed the expected susceptibility profiles on the differential lines based on their pathotypes, VI, VII, and VIII, respectively (Table 2). The TAS-ELISA detection method confirmed presence of the virus in every single leaf of infected cultivars Dubbele Witte, Stringless Green Refugee, Redlands Greenleaf C, Redlands Greenleaf B, and Sanilac (inoculated leaves at 2 wpi and upper noninoculated leaves at 5 wpi) exhibiting symptoms (Table 2, Fig. 1). Cultivar UI 35 inoculated with the isolate RU1-OR exhibited 88\% average infection rate among all the upper, noninoculated leaves at 5 wpi, i.e., $88 \%$ of upper, noninoculated leaves exhibited symptoms and

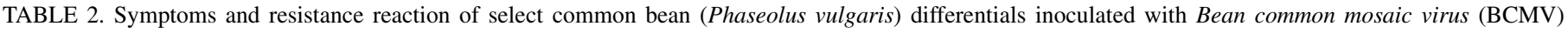
isolates $^{\mathrm{a}}$

\begin{tabular}{|c|c|c|c|c|c|c|c|c|c|}
\hline \multirow{2}{*}{$\begin{array}{l}\text { Bean } \\
\text { cultivar }^{\mathrm{b}}\end{array}$} & \multirow{2}{*}{$\begin{array}{l}\text { Resistance } \\
\text { genes }\end{array}$} & \multicolumn{8}{|c|}{$\mathrm{BCMV}$ isolates tested } \\
\hline & & 3PF (PG-I) & Viva2 (PG-I) & 313615 (PG-I) & PG1 (PG-I) & 3915 (PG-IV) & RU1-P (PG-VI) & RU1-OR (PG-VII) & 1755a (PG-VIII) \\
\hline DW & None & $+/ \mathrm{S}$ & $+/ S$ & $+/ S$ & $+/ \mathrm{S}$ & $+/ \mathrm{S}$ & $+/ \mathrm{S}$ & $+/ \mathrm{S}$ & $+/ \mathrm{S}$ \\
\hline SGR & $i, b c-u$ & $+/ \mathrm{S}$ & $+/ S$ & $+/ \mathrm{S}$ & $+/ \mathrm{S}$ & $+/ \mathrm{S}$ & $+/ \mathrm{S}$ & $+/ S$ & $+/ \mathrm{S}$ \\
\hline RGLC & $i, b c-u, b c-1$ & $-/ \mathrm{PR}$ & $-/ \mathrm{PR}$ & $-/ \mathrm{PR}$ & $-/ \mathrm{R}$ & $+/ \mathrm{S}$ & $+/ \mathrm{S}$ & $+/ \mathrm{S}$ & $-/ \mathrm{R}$ \\
\hline RGLB & $i, b c-u, b c-1^{2}$ & $-/ \mathrm{PR}$ & $-/ \mathrm{PR}$ & $-/ \mathrm{PR}$ & $-/ \mathrm{R}$ & $+/ \mathrm{S}$ & $+/ \mathrm{S}$ & $+/ \mathrm{S}$ & $-/ \mathrm{PR}$ \\
\hline Sanilac & $i, b c-u, b c-2$ & $-/ \mathrm{PR}$ & $-/ \mathrm{PR}$ & $-/ \mathrm{PR}$ & $-/ \mathrm{PR}$ & $-/ \mathrm{PR}$ & $+/ \mathrm{S}$ & $-/ \mathrm{PR}$ & $+/ \mathrm{S}$ \\
\hline UI 35 & $i, b c-u, b c-1^{2}, b c-2^{2}$ & $-/ \mathrm{PR}$ & $-/ \mathrm{PR}$ & $-/ \mathrm{PR}$ & $-/ \mathrm{R}$ & $-/ \mathrm{R}$ & $-/ \mathrm{PR}$ & $+/ \mathrm{PR}$ & $-/ \mathrm{R}$ \\
\hline IVT7214 & $i, b c-u, b c-2, b c-3$ & $-/ \mathrm{IM}$ & $-/ \mathrm{IM}$ & $-/ \mathrm{IM}$ & $-/ \mathrm{IM}$ & $-/ \mathrm{IM}$ & $-/ \mathrm{IM}$ & $-/ \mathrm{IM}$ & $+/ \mathrm{S}$ \\
\hline
\end{tabular}

a Disease reaction as measured by symptom expression and triple-antibody sandwich-enzyme linked immunosorbent assay (TAS-ELISA) assessment of BCMV infection of both primary inoculated and upper uninoculated leaves in different genotypes. Two or three plants were inoculated for each BCMV isolate per experiment. Primary inoculated leaves were tested at 2 weeks postinoculation (wpi) and upper uninoculated leaves were tested at 5 wpi. Numerator: $+=$ symptoms on inoculated plants; - = no symptoms on inoculated plants; and denominator: S, susceptible, designates virus was able to replicate and spread to the entire plant; IM, immune, designates no virus was found in either primary inoculated leaves or upper noninoculated leaves; R, resistant, designates virus found replicating and moving normally in primary inoculated leaves but unable to move beyond the inoculated leaves; PR, partially resistant, designates viruses able to replicate and move from cell-to-cell in primary inoculated leaves, but their long-distance movement ability was impaired and infection could only be found in a few upper noninoculated leaves.

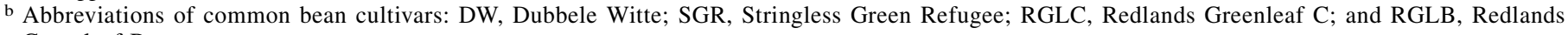
Greenleaf B. 
A

BCMV isolate-PG1

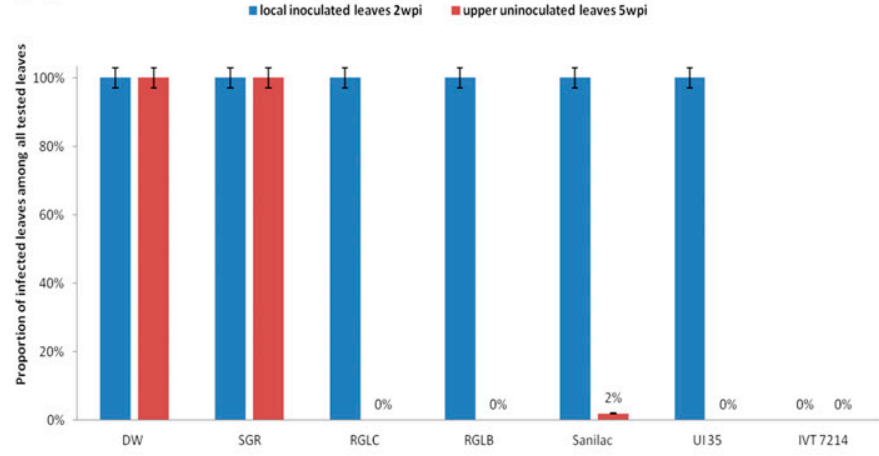

B

BCMV isolate-Viva2
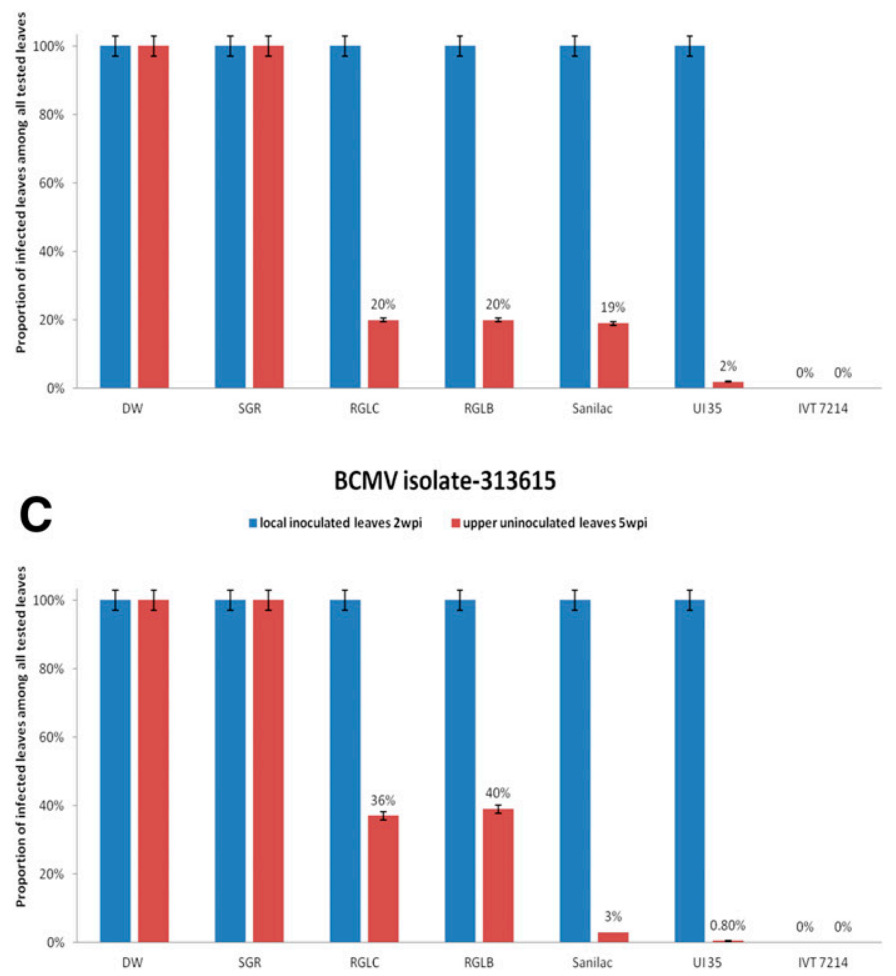

D

$\mathrm{BCMV}$ isolate-3PF

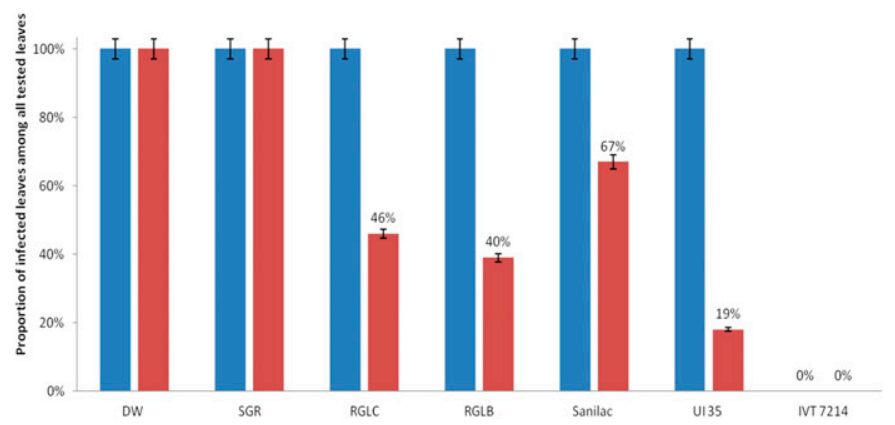

E

BCMV isolate-3915

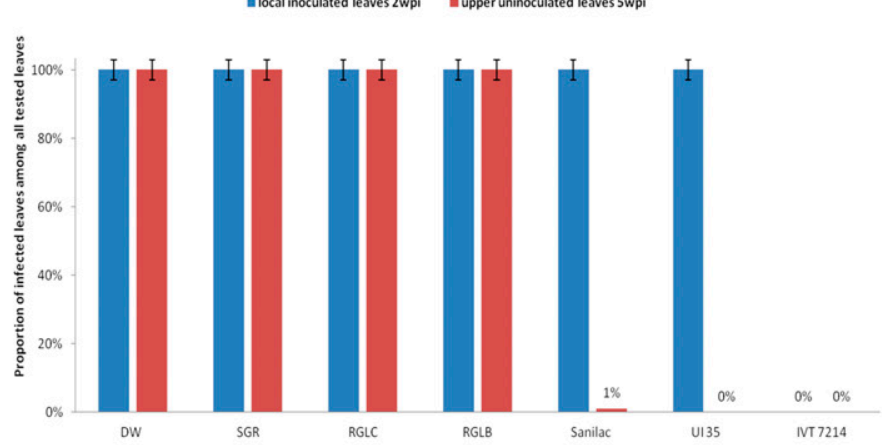

F

BCMV isolate-RU1-P
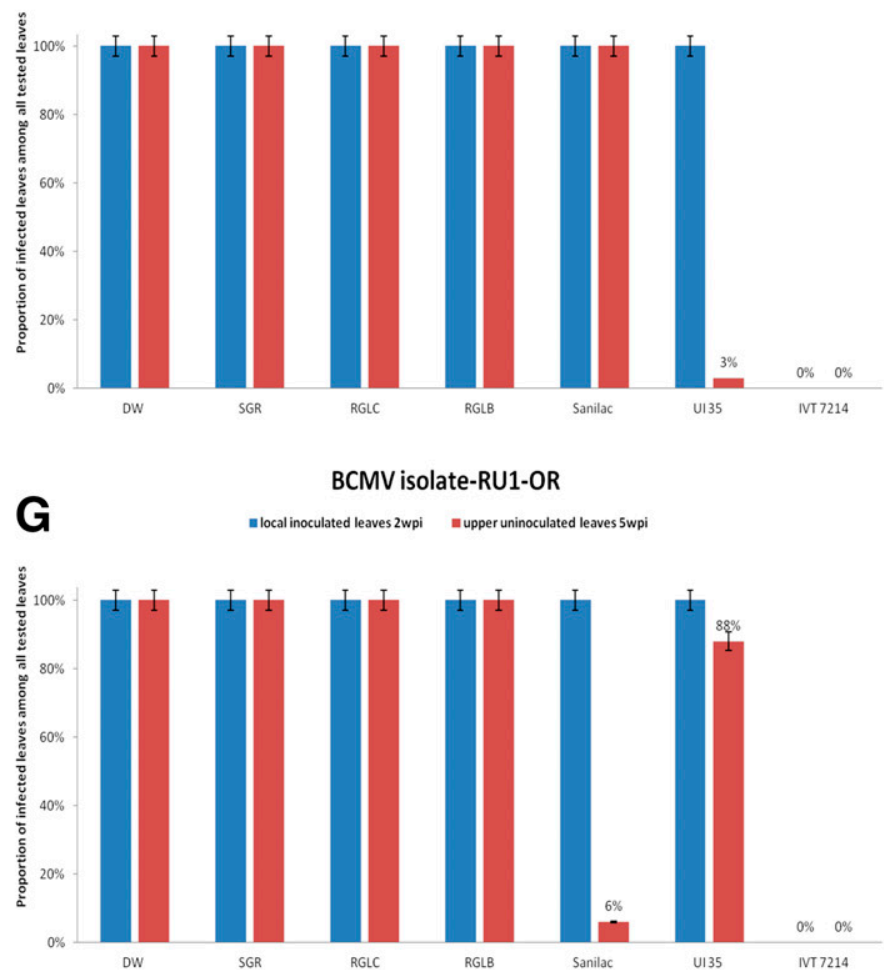

H

BCMV isolate-1755a

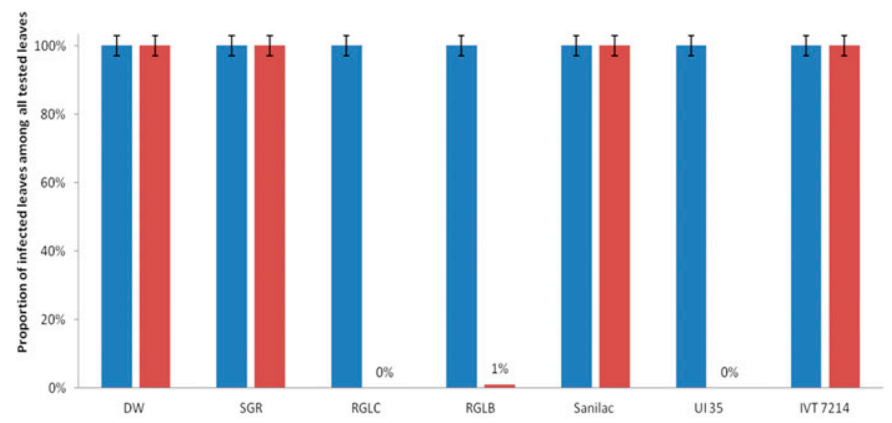

Fig. 1. A to H, Eight Bean common mosaic virus (BCMV) isolates were screened in seven common bean differentials carrying different recessive resistance genes. The upper noninoculated leaves were tested at 5 weeks postinoculation (wpi) by triple-antibody sandwich-enzyme linked immunosorbent assay (TAS-ELISA) for BCMV infection. The proportion of infected leaves per plant among all the tested leaves was calculated to assess cell-to-cell and long-distance movement ability of BCMV isolates in different common bean genotypes. Vertical bars represent the average inoculated and noninoculated leaf infection rate for two or three plants of the same cultivar analyzed by TAS-ELISA in the same experiment. Abbreviations of common bean cultivars: DW, Dubbele Witte; SGR, Stringless Green Refugee; RGLC, Redlands Greenleaf C; and RGLB, Redlands Greenleaf B. 
tested positive for BCMV by TAS-ELISA, with $12 \%$ of these same noninoculated leaves being asymptomatic and BCMV-negative. These cultivars were marked as susceptible to the corresponding isolates.

All inoculated and upper noninoculated leaves from bean differentials that did not exhibit visible systemic symptoms were also collected and tested by ELISA for the presence of BCMV the same way (Fig. 1). In cultivar IVT7214 (HG-7), no symptoms were observed and no virus was detected by ELISA test in either inoculated or upper, noninoculated leaves for all BCMV isolates except 1755a. Consequently, cultivar IVT7214 was assumed to be immune to all tested BCMV isolates except $1755 \mathrm{a}$. Interestingly, at 2 wpi, all the BCMV isolates were found replicating in all inoculated primary leaves of cultivars Redlands Greenleaf C (HG-2), Redlands Greenleaf B (HG-3), Sanilac (HG-4), and UI 35 (HG-6), as determined by ELISA, apparently to the same level as the virus infecting susceptible differentials Dubbele Witte and Stringless Green Refugee (Fig. 1). The average infection rate of upper noninoculated leaves determined at 5 wpi differed depending of the tested isolate and cultivar combination.

Assessment of the virus replication, cell-to-cell, and longdistance movement in common bean differentials carrying recessive resistance genes. ELISA testing of every single primary inoculated and upper noninoculated leaf of bean differentials inoculated with the eight BCMV under study was summarized in Table 2 and Figure 1. In cultivars Dubbele Witte and Stringless Green Refugee, with no resistance gene incorporated (Dubbele Witte) or with only $b c-u$ present (Stringless Green Refugee), all eight BCMV isolates had no difficulties to replicate or move in both inoculated and upper noninoculated leaves (100\% systemic infection). This implied virus could replicate and move freely cellto-cell in inoculated leaves, and spread systemically through the entire plant when no resistance gene was present or when only $b c-u$ was present.

In cultivars Redlands Greenleaf $\mathrm{C}$ and Redlands Greenleaf $\mathrm{B}, b c$ 1 or $b c-1^{2}$ alleles conferred resistance or partial resistance to BCMV isolates 3PF, Viva2, 313615, PG1, and 1755a (Fig. 1A to D and H). In cultivar Sanilac, $b c$-2 allele conferred resistance or partial resistance to 3PF, Viva2, 313615, PG1, 3915, and RU1-OR (Fig. 1A to E and $\mathrm{G})$. In all cases, virus replication and cell-to-cell movement in inoculated leaves were not affected (Fig. 1). The proportion of infected leaves among all the upper, noninoculated leaves was dependent on BCMV isolate and bean cultivar: for Redlands Greenleaf C and Redlands Greenleaf B carrying $b c-1$ or $b c-1^{2}$ allele, the average infection rate ranged from 0 (complete resistance) to $46 \%$ (partial resistance), while for Sanilac bearing $b c-2$ allele, the rate ranged from 1 (almost complete resistance) to $67 \%$ (partial resistance) (Fig. 1). This suggested $b c-1$ and $b c-2$ genes may not affect virus replication and cell-to-cell movement in the inoculated leaves, but they may play an important role in restricting virus longdistance movement in the plant, preventing or impairing systemic spread of the infection.

In cultivar UI 35 , where both $b c-1^{2}$ and $b c-2^{2}$ allele were present, they apparently conferred complete resistance or partial resistance to all the tested isolates except RU1-OR (Fig. 1). Again, the replication and cell-to-cell movement in inoculated leaves were not affected for any of the eight tested BCMV isolates, which was consistent with the profile exhibited in differentials bearing individual $b c-1$ or $b c-2$ allele. The infection rate of upper, noninoculated leaves of UI 35 varied from 0 (complete resistance) to $88 \%$ (very weak partial resistance) (Fig. 1). For most of the isolates, resistance conferred by two recessive genes (bc- 1 and $b c-2)$ to BCMV isolates was more effective than that conferred by a single recessive gene (bc-1 or $b c-2)$ (Fig. 1).

Whole genome sequencing and sequence analysis. The whole genomes of BCMV isolates 3915, 3PF, Viva2, 313615, and PG1 were cloned and sequenced, using the approach described previously (Feng et al. 2014b). Upon sequence assembly, all five isolates were found to be 10,053-nucleotides (nts) long, excluding the poly(A). Based on conceptual translation, all genomes encoded a single polyprotein of the same size of 3,222 amino acids (aa). The whole genome of BCMV isolate RU1-CA was also cloned and sequenced as described. Upon sequence assembly, RU1-CA was found to be 10,001-nt long, excluding the poly(A). Based on conceptual translation, RU1-CA genome encoded a single polyprotein of 3,202 aa. The coding region for RU1-CA spanned nucleotides 141 to 9749 , total 9,609 nts; the coding regions for Viva2, 3PF, 313615, and PG1 all spanned nucleotides 131 to 9799 , and the coding region for 3915 spanned nucleotides 132 to 9800 , total 9,669 nts for all five of them. Hence, the $5^{\prime}$-untranslated region (UTR) of the RU1 strain was slightly (10 nts) longer than for US1/ NL1 strains, but the coding region in US1/NL1 types was $60 \mathrm{nts}$ longer than in RU1 type. The 3'-UTR of the RU1 genome was 2 nts shorter than the $3^{\prime}$-UTR of the US-NL1 genomes. These slight differences between sizes of coding and noncoding regions accounted for the observed 20-aa shorter polyprotein of the RU1 strain relative to only 52-nt shorter genome.

The sequences of all six isolates were compared with the known BCMV genomes using the BLASTn 2.2.17 tool (Altschul et al. 1997), and the 3PF and Viva2 sequences were $99 \%$ identical to the BCMV strain 2 Iowa sequence (GenBank accession number KU896809), and also 99\% identical to the BCMV-NY15p sequence (PG-V; KT175568). Sequences for the isolates 313615 and PG1 shared the closest identities to the NL1 (95 and 92\% identical to NL1 [PG-I, AY112735], respectively). The whole genome sequence of isolate 3915 was $96 \%$ identical to the BCMV isolate NL1 (PG-I; AY112735) and 95\% identical to BCMV strain 2 Iowa sequence (KU896809). The whole genome of RU1-CA shared 99\% identities to RU1-D (PG-VI; GQ219793) and RU1-P (PG-VI; KF919300).

The whole genomes for NL1 (PG-I; AY112735), 1755a (PGVIII; KT175570), and 3915 (PG-IV; MH024842), together with PG1 (PG-I; MH024838), Viva 2 (PG-I; MH024839), 313615 (PG-I; MH024840), and 3PF (PG-I; MH024841) were aligned using CLUSTALX and further analysis was conducted with the RDP4 program package. Figure $2 \mathrm{~A}$ shows the comparison of the six sequences using the manual distance plot analysis, with the full-length NL1 sequence used as reference. As can be seen from Figure 2A, most of the sequence diversity between BCMV isolates studied was concentrated in two areas: the P1/HC-Pro area, nucleotides 1 to 2577 , and the NIa/NIb area, nucleotides 5955 to 9028 . When the same sequences were analyzed against isolate $1755 \mathrm{a}$ as a reference, the area of divergence potentially affecting BCMV isolates' pathogenicity in a $b c$-2 genotype (cultivar Sanilac) was found in the 5 '-terminal region spanning P1, HC-pro, and P3 cistron, nucleotides 1 to 3829 (Fig. 2B).

\section{DISCUSSION}

In the past, with a limited set of laboratory tools available to confirm infection, conclusions on susceptibility or resistance to a virus were based on symptom observations, and on back inoculations to indicator plants. The classical study of the genetics of resistance to BCMV in common bean was conducted in the early to mid-1970s and relied only on visual symptom observations and back inoculations to a susceptible host (Drijfhout 1978). At that time, a closely related potyvirus, BCMNV was considered a strain of BCMV, and hence treated accordingly, being listed as a set of NL3, NL-5, and NL-8 strains of BCMV (Drijfhout 1978). Later, based on serological and molecular evidence, BCMNV was recognized as a distinct virus species (Berger et al. 1997; McKern et al. 1992; Mink and Silbernagel 1992; Vetten et al. 1992) exhibiting very limited genetic diversity between these established strains (Feng et al. 2017; Larsen et al. 2005, 2011; Strausbaugh et al. 2003). Recently, the NL-8 strain of BCMNV was demonstrated to have impaired systemic movement in common bean cultivars expressing $b c-1$ or $b c-1^{2}$ resistance alleles, exhibiting incomplete, partial resistance (Feng et al. 2017). Here, we established the same $b c-1$ 


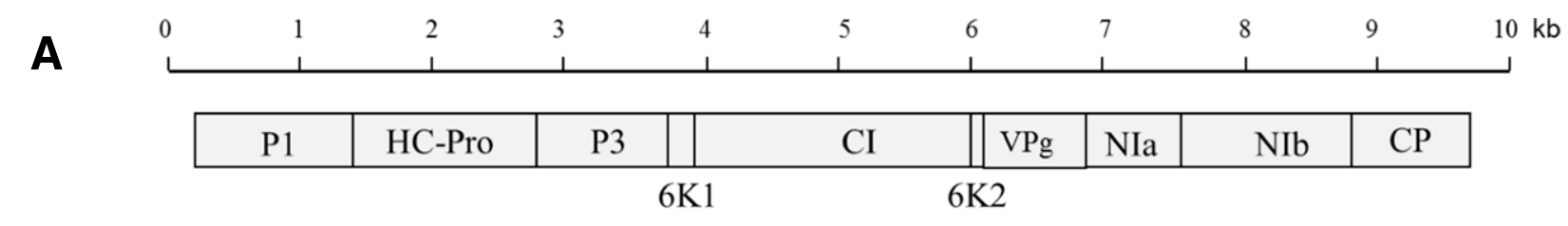
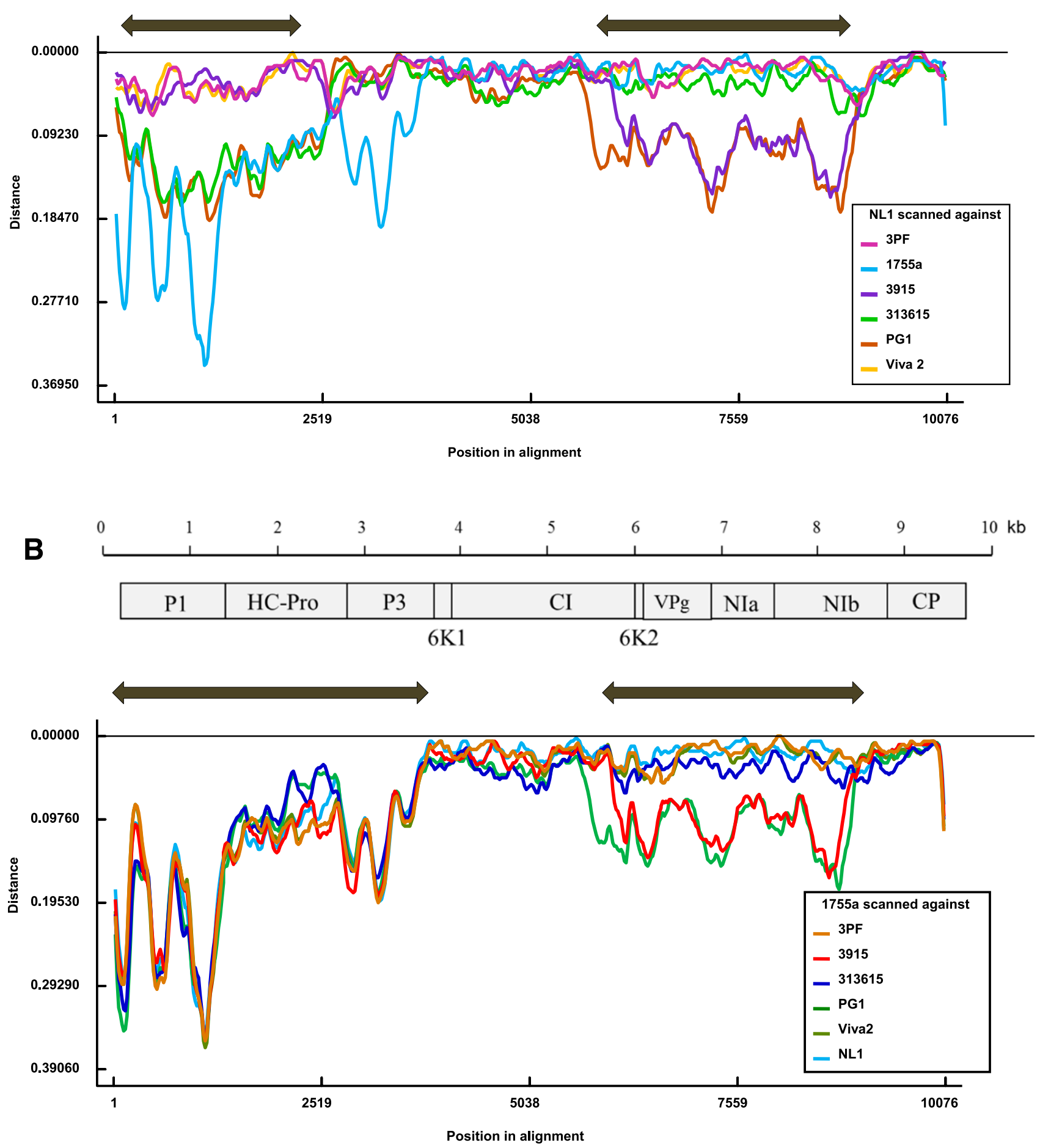

Fig. 2. Recombination analysis of the five studied Bean common mosaic virus (BCMV) isolates, 3915, 3PF, Viva2, 313615, and PG1, in comparison with the control BCMV isolates 1755a and NL1. A, Manual distance plot based on the aligned full-length nucleotide sequences of BCMV isolates 3915, 3PF, Viva2, 313615, PG1, 1755a, and NL1. Sequence of isolate NL1 (PG-I; accession number AY112735) was used as the reference. B, Manual distance plot based on the aligned full-length nucleotide sequences of BCMV isolates 3915, 3PF, Viva2, 313615, PG1, 1755a, and NL1. Sequence of isolate 1755a (PG-VIII; accession number KT175570) was used as the reference. $\mathrm{x}$-axis represents nucleotide position in the alignment, $y$-axis represents relative distance from the reference sequence, calculated using the Kimura model (Kimura 1980). 
role in the impairment of the systemic movement for BCMV infection, and not only for the two $b c-1$ alleles, but also for both $b c-2$ and $b c-2^{2}$ alleles as well. Importantly, we found that the resistance exhibited by all four alleles of the $b c-1$ and $b c-2$ genes was expressed as an incomplete or partial resistance (Cooper and Jones 1983) to many BCMV isolates, identified only when a laboratory detection method was used (Fig. 1). It is quite possible that the partial resistance nature of $b c-1$ and $b c$-2 alleles was not noticed previously (Drijfhout 1978) merely due to the technical limitations of the time.

Dominant RTM genes were found to control restricted systemic movement of Tobacco etch virus (TEV) in Arabidopsis thaliana, conferring resistance against three potyviruses (Mahajan et al. 1998). Similarly, Wsml and Wsm2, two dominant resistance genes restricted systemic movement of two potyviruses in wheat (Tatineni et al. 2016). Two recessive resistance genes, $r a$ in potato, and sha 3 in A. thaliana, were identified to confer resistance to Potato virus A and to Plum pox virus, respectively, through restriction of systemic spread of the virus (Hamalainen et al. 2000; Pagny et al. 2012). Recently, two alleles of the recessive $b c-1$ resistance gene were found to affect systemic spread of BCMNV in common bean (Feng et al. 2017). The exact nature and mechanism of expression of these resistance genes were unknown. But a recessive eIF4(iso)4E translation initiation factor gene was implicated in long distance movement of TEV in A. thaliana (Contreras-Paredes et al. 2013). Here, we demonstrated that $b c-1$ alleles were involved in restriction of systemic movement not only for BCMNV (Feng et al. 2017), but also for another potyvirus, BCMV (Fig. 1; Table 2). The restriction of the systemic movement conferred by the $b c$-2 alleles may be more specific to BCMV (Fig. 1; Table 2), although effects on BCMNV may be difficult to assess due to the low genetic and phenotypic diversity of the currently known BCMNV isolates (Feng et al. 2017).

Systemic spread of potyviruses was found to be controlled by three different cistrons, capsid protein (CP) (Carbonell et al. 2013; Decroocq et al. 2009; Desbiez et al. 2014; Dolja et al. 1995; Tatineni et al. 2011), VPg (Hamalainen et al. 2000; Rajamaki and Valkonen 1999, 2002; Schaad et al. 1997), and 6K2 (Rajamaki and Valkonen 1999). The most diverse regions in the eight studied BCMV genomes, however, were in the 5' -proximal cistrons, P1, HC-Pro, and P3 (Fig. 2). Interestingly, in the BCMNV system, no amino acid substitutions correlating with the observed restriction of the systemic movement of NL-8-like isolates in common bean cultivars expressing $b c-1$ alleles, were found in 6K2, VPg, and CP of BCMNV (Feng et al. 2017). The BCMV genetic determinants involved in overcoming the restrictions in systemic movement of the virus need to be defined directly through reverse genetics experimentation.

In breeding for resistance to BCMV, breeders tended to focus on genes conferring broad spectrum, non-strain-specific resistance, like $I$ and $b c-3$ genes (Kelly et al. 1995; Singh and Schwartz 2010). However, wide use of the $I$ gene led to potential vulnerability of these common bean genotypes to the BCMNV infection which induced rapid systemic necrosis in $I$-gene bearing cultivars even below $30^{\circ} \mathrm{C}$ (Ali 1950; Collmer et al. 2000; Feng et al. 2017). On the other hand, a recently described isolate of BCMV, 1755a, was able to overcome the $b c-3$ resistance gene (Feng et al. 2015). The data presented here suggest that the use of the two other resistance genes, $b c-1$ and $b c-2$, in particular in combinations with each other and with other, non-strain-specific resistance genes may provide superior results in breeding for BCMV resistance, restricting or impairing the systemic spread of the virus in a plant. The prevalence of $b c-1$, $b c-1^{2}, b c-2$, and $b c-2^{2}$ among cultivars, heirloom, and landrace bean accessions is notable. Of the 433 bean accessions screened by Drijfhout (1978), 58\% had no resistance genes, but among those with some form of resistance, $23 \%$ had an allele of $b c-1$ or $b c-2$, either singly or in various combinations. Another $12 \%$ of accessions that possessed $I$ also had one or more of the $b c-1$ or $b c-2$ alleles. The most common recessive gene allele was $b c-1(12 \%)$ followed by $b c-1^{2}$ $(5 \%)$. Whether this phenomenon may represent some form of unconscious (or natural) selection for BCMV resistance by breeders in the past remains to be determined. The data from this research suggest that $b c-1$ and $b c-2$ alleles provide good to very good resistance to many BCMV strains, especially if deployed in combinations with each other or with other resistance genes.

\section{ACKNOWLEDGMENTS}

The authors are grateful to P. Guzman (California Crop Improvement Association, Davis) and to J. Thayer (Washington State University, Pullman) for providing the BCMV-positive samples of individual virus isolates, and to J. Chojnacky for laboratory and greenhouse help.

\section{LITERATURE CITED}

Adams, M. J., Zerbini, F. M., French, R., Rabenstein, F., Stenger, D. C., and Valkonen, J. P. T. 2012. Family Potyviridae. Pages 1069-1089 in: Virus Taxonomy. Ninth Report of the International Committee on Taxonomy of Viruses. A. King, M. Adams, E. Carstens, and E. Lefkowitz, eds. Elsevier, Oxford.

Ali, M. A. 1950. Genetics of resistance to the common bean mosaic virus (bean virus 1) in the bean (Phaseolus vulgaris L.). Phytopathology 40:69-79.

Altschul, S. F., Madden, T. L., Schaffer, A., Zhang, J., Zhang, Z., Miller, W., and Lipman, D. J. 1997. Gapped BLAST and PSI-BLAST: A new generation of protein database search programs. Nucleic Acids Res. 25:3389-3402.

Berger, P. H., Wyatt, S. D., Shiel, P. J., Silbernagel, M. J., Druffel, K., and Mink, M. I. 1997. Phylogenetic analysis of the Potyviridae with emphasis on legume-infecting potyviruses. Arch. Virol. 142:1979-1999.

Bos, L. 1971. Bean common mosaic virus. Descriptions of Plant Viruses 73. Association of Applied Biologists.

Cadle-Davidson, M. M., and Jahn, M. 2005. Resistance conferred against Bean common mosaic virus by the incompletely dominant $I$ locus of Phaseolus vulgaris is active at the single cell level. Arch. Virol. 150:2601-2608.

Carbonell, A., Maliogka, V. I., Pérez, J. J., Salvador, B., San León, D., García, J. A., and Simón-Mateo, C. 2013. Diverse amino acid changes at specific positions in the $\mathrm{N}$-terminal region of the coat protein allow Plum pox virus to adapt to new hosts. Mol. Plant-Microbe Interact. 26:1211-1224.

Chung, B. Y., Miller, W. A., Atkins, J. F., and Firth, A. E. 2008. An overlapping essential gene in the Potyviridae. Proc. Natl. Acad. Sci. USA 105: 5897-5902.

Collmer, C. W., Marston, M. F., Taylor, J. C., and Jahn, M. 2000. The I gene of bean: A dosage-dependent allele conferring extreme resistance, hypersensitive resistance, or spreading vascular necrosis in response to the potyvirus Bean common mosaic virus. Mol. Plant-Microbe Interact. 13:1266-1270.

Contreras-Paredes, C. A., Silva-Rosales, L., Daros, J. A., Alejandri-Ramirez, N. D., and Dinkova, T. D. 2013. The absence of eukaryotic initiation factor eIF(iso)4E affects the systemic spread of a Tobacco etch virus isolate in Arabidopsis thaliana. Mol. Plant-Microbe Interact. 26:461-470.

Cooper, J. I., and Jones, A. T. 1983. Responses of plants to viruses: Proposals for the use of terms. Phytopathology 73:127-128.

Decroocq, V., Salvador, B., Sicard, O., Glasa, M., Cosson, P., Svanella-Dumas, L., Revers, F., Garcia, J. A., and Candresse, T. 2009. The determinant of potyvirus ability to overcome the RTM resistance of Arabidopsis thaliana maps to the N-terminal region of the coat protein. Mol. Plant-Microbe Interact. 22:1302-1311.

Desbiez, C., Chandeysson, C., and Lecoq, H. 2014. A short motif in the Nterminal part of the coat protein is a host-specific determinant of systemic infectivity for two potyviruses. Mol. Plant Pathol. 15:217-221.

Dolja, V. V., Haldeman-Cahill, R., Montgomery, A. E., Vandenbosch, K. A., and Carrington, J. C. 1995. Capsid protein determinants involved in cell-tocell and long-distance movement of Tobacco etch potyvirus. Virology 206: 1007-1016.

Drijfhout, E. 1978. Genetic interaction between Phaseolus vulgaris and Bean common mosaic virus with implications for strain identification and breeding for resistance. Centre for Agricultural Publication and Documents, Wageningen, The Netherlands.

Drijfhout, E. 1991. Bean common mosaic. Pages 37-39 in: Compendium of Bean Diseases. American Phytopathological Society, St. Paul, MN.

Drijfhout, E., and Morales, F. 2005. Bean common mosaic. Pages 60-62 in: Compendium of Bean Diseases, 2nd ed. H. F. Schwartz, J. R. Steadman, R. Hall, and R. L. Forster, eds. American Phytopathological Society, St. Paul, MN

Feng, X., Guzmán, P., Myers, J. R., and Karasev, A. V. 2017. Resistance to Bean common mosaic necrosis virus conferred by the $b c-1$ gene affects systemic spread of the virus in common bean. Phytopathology 107:893-900.

Feng, X., Myers, J. R., and Karasev, A. V. 2015. Bean common mosaic virus isolate exhibits a novel pathogenicity profile in common bean, overcoming 
the $b c-3$ resistance allele coding for the mutated eIF4E translation initiation factor. Phytopathology 105:1487-1495.

Feng, X., Poplawsky, A. R., and Karasev, A. V. 2014a. A recombinant of Bean common mosaic virus induces temperature-insensitive necrosis in an I genebearing line of common bean. Phytopathology 104:1251-1257.

Feng, X., Poplawsky, A. R., Nikolaeva, O. V., Myers, J. R., and Karasev, A. V. 2014b. Recombinants of Bean common mosaic virus (BCMV) and genetic determinants of BCMV involved in overcoming resistance in common beans. Phytopathology 104:786-793.

Fisher, M. L., and Kyle, M. M. 1994. Inheritance of resistance to potyviruses in Phaseolus vulgaris L. III. Cosegregation of phenotypically similar dominant responses to nine potyviruses. Theor. Appl. Genet. 89:818-823.

Flasinski, S., Gunasinghe, U. B., Gonzales, R. A., and Cassidy, B. G. 1996. The cDNA sequence and infectious transcripts of peanut stripe virus. Gene 171:299-300.

Flores-Estevez, N., Acosta-Gallegos, J. A., and Silva-Rosales, L. 2003. Bean common mosaic virus and Bean common mosaic necrosis virus in Mexico. Plant Dis. 87:21-25.

Hamalainen, J. H., Kekarainen, T., Gebhardt, C., Watanabe, K. N., and Valkonen, J. P. T. 2000. Recessive and dominant genes interfere with the vascular transport of Potato virus A in diploid potatoes. Mol. Plant-Microbe Interact. 13:402-412.

Hart, J. P., and Griffiths, P. D. 2013. A series of $e I F 4 E$ alleles at the $B c-3$ locus are associated with recessive resistance to Clover yellow vein virus in common bean. Theor. Appl. Biol. 126:2849-2863.

Kelly, J. D., Afanador, L., and Haley, S. D. 1995. Pyramiding genes for resistance to Bean common mosaic virus. Euphytica 82:207-212.

Kimura, M. 1980. A simple method for estimating evolutionary rates of base substitutions through comparative studies of nucleotide sequences. J. Mol. Evol. 16:111-120.

Larsen, R. C., Druffel, K. L., and Wyatt, S. D. 2011. The complete nucleotide sequences of bean common mosaic necrosis virus strains NL-5, NL-8 and TN-1. Arch. Virol. 156:729-732.

Larsen, R. C., Miklas, P. N., Druffel, K. L., and Wyatt, S. D. 2005. NL-3 K strain is a stable and naturally occurring interspecific recombinant derived from Bean common mosaic necrosis virus and Bean common mosaic virus. Phytopathology 95:1037-1042.

Li, Y., Cao, Y., Fan, Z., and Wan, P. 2016. Identification of a naturally occurring Bean common mosaic virus recombinant isolate infecting azuki bean. J. Plant Pathol. 98:129-133.

Mahajan, S. K., Chisholm, S. T., Whitham, S. A., and Carrington, J. C. 1998. Identification and characterization of a locus (RTM1) that restricts long-distance movement of Tobacco etch virus in Arabidopsis thaliana. Plant J. 14:177-186.

Martin, D. P., Williamson, C., and Posada, D. 2005. RDP2: Recombination detection and analysis from sequence alignments. Bioinformatics 21:260-262.

McKern, N. M., Mink, G. I., Barnett, O. W., Mishra, A., Whittaker, L. A., Silbernagel, M. J., Ward, C. W., and Shukla, D. D. 1992. Isolates of Bean common mosaic virus comprising two distinct potyviruses. Phytopathology 82:923-929.

Mink, G. I., and Silbernagel, M. J. 1992. Serological and biological relationships among viruses in the Bean common mosaic virus subgroup. Arch. Virol. Suppl. 5:397-406.
Morales, F. J., and Bos, L. 1988. Bean common mosaic virus. Descriptions of Plant Viruses, No. 337. http://www.dpvweb.net/dpv/showdpv.php?dpvno=337

Naderpour, M., and Johansen, I. E. 2011. Visualization of resistance responses in Phaseolus vulgaris using reporter tagged clones of Bean common mosaic virus. Virus Res. 159:1-8.

Naderpour, M., Lund, O. S., and Johansen, I. E. 2009. Sequence analysis of expressed cDNA of Bean common mosaic virus RU1 isolate. Iran J. Virol. 3:41-43.

Naderpour, M., Lund, O. S., Larsen, R., and Johansen, E. 2010. Potyviral resistance derived from cultivars of Phaseolus vulgaris carrying $b c-3$ is associated with the homozygotic presence of a mutated $e I F 4 E$ allele. Mol. Plant Pathol. 11:255-263.

Pagny, G., Paulstephenraj, P. S., Poque, S., Sicard, O., Cosson, P., Eyquard, J. P., Caballero, M., Chague, A., Gourdon, G., Negrel, L., Candresse, T., Mariette, S., and Decroocq, V. 2012. Family-based linkage and association mapping reveals novel genes affecting Plum pox virus infection in Arabidopsis thaliana. New Phytol. 196:873-886.

Rajamaki, M. L., and Valkonen, J. P. T. 1999. The 6K2 protein and the VPg of Potato virus $A$ are determinants of systemic infection in Nicandra physaloides. Mol. Plant-Microbe Interact. 12:1074-1081.

Rajamaki, M. L., and Valkonen, J. P. T. 2002. Viral genome-linked protein (VPg) controls accumulation and phloem-loading of a potyvirus in inoculated potato leaves. Mol. Plant-Microbe Interact. 15:138-149.

Schaad, M. C., Lellis, A. D., and Carrington, J. C. 1997. VPg of tobacco etch potyvirus is a host genotype-specific determinant for long-distance movement. J. Virol. 71:8624-8631.

Singh, S., and Schwartz, H. F. 2010. Breeding common bean for resistance to diseases: A review. Crop Sci. 50:2199-2223.

Strausbaugh, C. A., Miklas, P. N., Singh, S. P., Myers, J. R., and Forster, R. L. 2003. Genetic characterization of differential reactions among host group 3 common bean cultivars to NL-3 K strain of Bean common mosaic necrosis virus. Phytopathology 93:683-690.

Tatineni, S., Van Winkle, D. H., and French, R. 2011. The N-terminal region of Wheat streak mosaic virus coat protein is a host- and strain-specific longdistance transport factor. J. Virol. 85:1718-1731.

Tatineni, S., Wosula, E. N., Bartels, M., Hein, G. L., and Graybosch, R. A. 2016. Temperature-dependent Wsm1 and Wsm2 gene-specific blockage of viral long-distance transport provides resistance to Wheat streak mosaic virus and Triticum mosaic virus in wheat. Mol. Plant-Microbe Interact. 29: 724-738.

Vetten, H. J., Lesemann, D. E., and Maiss, E. 1992. Serotype A and B strains of Bean common mosaic virus are two distinct potyviruses. Arch. Virol. Suppl. 5:415-431.

Wei, T., Zhang, C., Hong, J., Xiong, R., Kasschau, K. D., Zhou, X., Carrington, J. C., and Wang, A. 2010. Formation of complexes at plasmodesmata for potyvirus intercellular movement is mediated by the viral protein P3N-PIPO. PLoS Pathog 6:e1000962.

Zhou, G. C., Wu, X. Y., Zhang, Y. M., Wu, P., Wu, X. Z., Liu, L. W., Wang, Q., Hang, Y. Y., Yang, J. Y., Shao, Z. Q., Wang, B., and Chen, J. Q. 2014. A genomic survey of thirty soybean-infecting Bean common mosaic virus (BCMV) isolates from China pointed BCMV as a potential threat to soybean production. Virus Res. 191:125-133. 